\title{
Los 55 años del Laboratorio Nacional de Aguas (1964-2019)
}

Darner A. Mora-Alvarado ${ }^{1}$

https://doi.org/10.18845/tm.v32i10.4875

El 14 de abril de 1961, durante la administración del Lic. Mario Echandi Jiménez, inició funciones el "Servicio Nacional de Acueductos y Alcantarillados" (SNAA). Su fundamento legal fue la Ley 2726, y su principal propósito consistió en atender la crisis en el suministro de agua para consumo humano y alcantarillado en el Área Metropolitana de San José. En este contexto, y con el objetivo de vigilar y controlar la calidad del agua suministrada por las plantas, tanto potabilizadoras como de aguas residuales, se crea el "Laboratorio Central" (LC). Su sede se ubicó en la comunidad de Tres Ríos, en el centro del cantón de La Unión, iniciando funciones el 20 de setiembre de 1964 con la participación de 11 funcionarios, bajo el liderazgo persistente del Dr. Edgar Ortiz Castro (q.d.D.g.). Las instalaciones se localizaron en una casa construida en 1920, que se encontraban en las cercanías de la Planta Baja de Potabilización de AyA.

En concordancia con las funciones rectoras y operadoras del SNAA (hoy AyA), además de las obligaciones mencionadas y atribuidas por Ley, el LC también abordó la capacitación de funcionarios de plantas potabilizadoras, muestreo e inspecciones sanitarias, además de la vigilancia de la calidad del agua en sus diferentes usos. Posteriormente, y debido a la ampliación del SNAA a otras áreas urbanas del país, el LC fue creciendo en cumplimiento de sus nuevos objetivos. En la década de los años 70 incursionó en el muestreo y análisis de aguas marinas, específicamente de las playas de Limón y Puntarenas. Paralelamente, ingresaron a trabajar varios funcionarios graduados que fungieron como asistentes y luego como profesionales, entre los que podemos citar a los doctores en microbiología Ana Victoria Mata, Juan Carlos Rojas, Edgar González y Darner Mora, y los licenciados en química Victoria Pacheco, Marco Sequeira y José Miguel Ramírez, estos nuevos funcionarios impulsaron y realizaron estudios especiales en temas vinculados con el agua, el ambiente y la salud, entre los que se pueden citar::

- Estudio de la Calidad Sanitaria de la Playa de Limón Centro: 1981-1984.

- Criterios Bacteriológicos y Calidad Sanitaria de las Aguas de Playas de Costa Rica: 19861987.

- Evaluación de la Contaminación Orgánica de la Cuenca Virilla-Tárcoles: 1981-1985.

1 Director del Laboratorio Nacional de Aguas. Acueductos y Alcantarillados

(AYA). Costa Rica. Correo electrónico: dmora@aya.go.cr 
- Evaluación de la Contaminación Fecal del Río Barranca.

Años después, sus estudios sirvieron de insumo para el desarrollo de proyectos como el "Emisario Submarino de Limón" y "Mejoramiento Ambiental de San José", ambos fundamentales para el tratamiento de las aguas residuales y el mejoramiento del saneamiento en el país.

Entre 1990 y 1995, ante la emergencia provocada por la epidemia del cólera, el LC jugó un papel preponderante en la detección del Vibrio cholerae y en la elaboración del "Plan Nacional para Prevenir el Cólera en Costa Rica". Aunado a esto, y como parte de la "Estrategia Nacional para Mejorar los Servicios de Agua Potable", se implementaron las siguientes acciones:

- Conformación de equipos de trabajo para atender el control de calidad del agua, con funcionarios del LC y las Oficinas Regionales de AyA.

- Se implementó el "Código de colores" en el año 1991 para medir los avances de la calidad microbiológica de las aguas para consumo humano, el cual fue posteriormente aprobado por la Organización Mundial de la Salud (OMS) en la tercera edición de las "Guías de Calidad del Agua" del año 2004.

- En 1996 se creó "Programa Bandera Azul Ecológica", que involucra y empodera a la sociedad civil en la protección de recurso hídrico, el ambiente y la salud pública.

Ante la idoneidad técnica demostrada por el LC durante todos esos años, éste fue designado como "Laboratorio Nacional de Aguas" (LNA) mediante el Decreto Ejecutivo 26066-S, que le brindó nuevas potestades y responsabilidades, como la vigilancia de la calidad del agua suministrada por los acueductos municipales y comunales.

En el año 2002, después de realizar un proyecto piloto en la comunidad de San Roque de Grecia, la Junta Directiva de AyA aprobó la creación del "Programa Sello de Calidad Sanitaria" mediante el Acuerdo 2002-158, con el objetivo de incentivar a los entes operadores de acueductos a suministrar agua de calidad potable, en forma sostenible y en armonía con la naturaleza. En el año 2006, y con el afán de cumplir las metas en agua para consumo de los pasados "Objetivos de Desarrollo del Milenio", promovidos por la OMS y el Fondo de las Naciones Unidas para la Infancia, se formalizó el "Programa Nacional de Mejoramiento y Sostenibilidad de la Calidad de los Servicios de Agua Potable: 2007-2015”, mediante el Decreto Ejecutivo 33953-MINAET-S, el cual sirvió de "catalizador" para ampliar la cobertura nacional con agua de calidad potable de $82,2 \%$ a 91,2\% entre los años 2007 y 2015.

En el año 2008 el LNA logra acreditar 52 determinaciones, el muestreo simple y compuesto y la gestión ante el Ente Costarricense de Acreditación, con la Norma INTE/ISO-IEC 17025: 2005, número que en la actualidad suma ya 130 determinaciones; por su parte, en el 2015 acredita también cinco tipos de inspecciones sanitarias, pero con la Norma INTE/ISO-IEC 17020: 2012.

Más adelante, y continuando con una filosofía proactiva, el LNA propuso a la administración superior de AyA el "Programa Nacional para Disminuir las Brechas en los Servicios de Agua Potable: 2019-2030", con el propósito de "no dejar a nadie atrás" en el acceso a este vital líquido, slogan de los nuevos "Objetivos de Desarrollo Sostenible". Aunado a esto, en marzo de 2018 la Agencia de Protección Ambiental de los EUA reconoció, después de varias pruebas científicas, al LNA como "Centro de Referencia en Análisis de Aguas Residuales para Centro América y Republica Dominicana", para el periodo 2019-2023.

A la luz de estos relevantes logros en 55 años de vigencia, y en un trabajo coordinado con el equipo editorial de la revista "Tecnología en Marcha", del Instituto Tecnológico de Costa Rica, se publica este número especial como homenaje y reconocimiento a la labor del LNA, que contiene los últimos doce estudios realizados por sus funcionarios en el periodo 2016-2019. 